\title{
Antitumor sterols from the mycelia of Cordyceps sinensis
}

\author{
Jin Woo Bok ${ }^{\mathrm{a}}$, Leonard Lermer ${ }^{\mathrm{a}}$, Jeff Chilton ${ }^{\mathrm{b}}$, Hans G. Klingeman ${ }^{\mathrm{c}}$, \\ G.H. Neil Towers ${ }^{\mathrm{a}, *}$

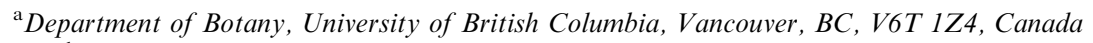 \\ ${ }^{\mathrm{b}}$ North American Reishi, Box 1780, Gibsons, British Columbia, V0N 1V0, Canada \\ ${ }^{\mathrm{c}}$ Department of Medicine, Terry Fox Laboratory, University of British Columbia, 601 West 10th, Vancouver, BC, V5X 1C3, Canada
}

Received 23 January 1998; received in revised form 2 October 1998; accepted 2 October 1998

\begin{abstract}
Activity guided fractionations led to the isolation of two antitumor compounds $5 \alpha, 8 \alpha$-epidioxy-24( $R$ )-methylcholesta-6,22dien-3 $\beta$-D-glucopyranoside and 5,6-epoxy-24( $R$ )-methylcholesta-7,22-dien-3 $\beta$-ol from the methanol extract of Cordyceps sinensis. Two previously known compounds, ergosteryl-3- $O$ - $\beta$-D-glucopyranoside and 22 -dihydroergosteryl-3- $O$ - $\beta$-D-glucopyranoside were also isolated. The structures of hitherto unknown sterols were established by 1D and 2D NMR spectroscopic techniques with the former synthesized in order to confirm the identity of the sugar moiety by chemical correlation. The glycosylated form of ergosterol peroxide was found to be a greater inhibitor to the proliferation of K562, Jurkat, WM-1341, HL-60 and RPMI-8226 tumor cell lines by 10 to $40 \%$ at $10 \mu \mathrm{g} / \mathrm{ml}$ than its previously identified aglycone, $5 \alpha, 8 \alpha$-epidioxy-24( $R$ )-methylcholesta-6,22-dien3 $\beta$-ol. (C) 1999 Elsevier Science Ltd. All rights reserved.
\end{abstract}

Keywords: Cordyceps sinenis; Antitumor activity; Steroidal glycosides

\section{Introduction}

Cordyceps sinensis (Berk.) Sacc. (family Clavicipitaceae) has long been used in Chinese medicine to treat numerous illnesses, promote longevity, relieve exhaustion and increase athletic prowess (Pegler, Yao \& Li, 1994; Steinkraus \& Whitfield, 1994; Jones, 1993; Tsunoo, Taketomo, Tsuboi, Kamijio, Nemoto, Sasaki, Uchida, Yamashita, Kinjo \& Haung, 1995). The medicinal preparation from the fruiting bodies of $C$. sinensis is named dong-chong-xia-cao which translates as winter worm and summer grass. $C$. sinensis infects the larvae of the sphinx moth, Hepialus armoricanus, found only in the highlands of the Himalayan region, and the larva hibernates underground through the winter. The fungus kills the infected host and grows throughout the cadaver, and in the summer, a rod-like stroma of the fungus grows

\footnotetext{
* Corresponding author.
}

out from the mummified shell of the dead host. Cordyceps species are generally known as the "caterpillar fungus' due to this characteristic parasitism of the living larvae of insects (Pegler, Yao \& Li, 1994; Steinkraus \& Whitfield, 1994; Jones, 1993).

A number of bioactive constituents from Cordyceps species have been reported. These include: cordycepin (Cunningham, Herchinson, Manson \& Spring, 1951; Kredich \& Guarino, 1960) and other antibacterial and antitumor adenosine derivatives (Furuya, Hirotani \& Matsuzawa, 1983), ophicordin, an antifungal agent (Kneifel, Srinivasan \& Maiti, 1957), a polysaccharide shown to have antitumor activity (Miyazaki, Oikawa \& Yamada, 1977; Yamada et al., 1984; Ohmori, Tamura, Tsuru \& Nomoto, 1986), an immunopotentiating galactomannan, and L-tryptophan (Zhang, Zhang, Zhu \& Chen, 1991). A recent report indicated that the fruiting body of $C$. sinensis contained growth inhibitors against tumor cells (K562, Vero, Wish, Calu-1 and Raji) other than cordycepin and polysaccharides (Kuo, Ching-Yuang Lin, Wei-Jern Tsai, Wu, 


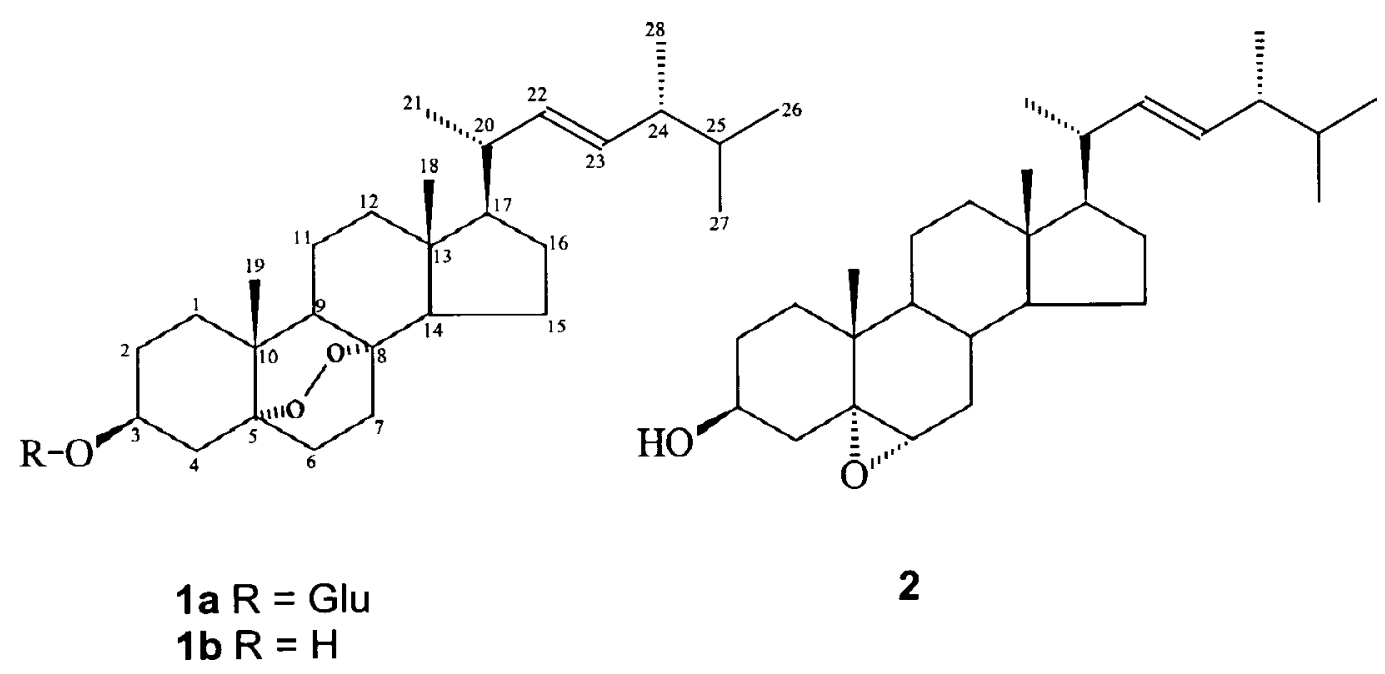

Chen \& Shiao, 1994). We report herein the isolation and identification of two antitumor compounds from the mycelia of $C$. sinensis. Activity guided chemical fractionations of the methanol extract of $C$. sinensis, led to the isolation of a steroidal glycoside $5 \alpha, 8 \alpha$-epidioxy-24( $R$ )-methylcholesta-6,22-dien-3 $\beta$-D-glucopyranoside (1a) and $5 \alpha, 6 \alpha$-epoxy-24( $R)$-methylcholesta7,22-dien-3 $\beta$-ol (2).

Two previously identified compounds, ergosteryl-3$O$ - $\beta$-D-glucopyranoside (3) and 22,23-dihydroergosteryl-3- $O-\beta$-D-glucopyranoside (4) were also isolated during the fractionation of the methanol extract (Shiao, Lin, Lien, Tzean \& Lee, 1989). These ergosterol derivatives were not active against the tumor cell lines used in this study.

\section{Results and discussion}

Compounds 3 and 4 were identified by ${ }^{1} \mathrm{H}$ NMR spectroscopy as ergosteryl-3- $O$ - $\beta$-D-glucopyranoside (3) and 22,23-dihydroergosteryl-3- $O$ - $\beta$-D-glucopyranoside (4) previously isolated from the fruiting body of $C$. sinensis (Shiao et al., 1989). Comparison of the ${ }^{1} \mathrm{H}$ NMR spectra of 1a with 3 and $\mathbf{4}$ suggests that 1a was also a glycoside derivative of a sterol. Compound 1a was found to have a $\left[\mathrm{M}+\mathrm{NH}_{4}\right]^{+}$peak from CI of $m / z$ $=608\left[\mathrm{C}_{34} \mathrm{H}_{54} \mathrm{O}_{8}+\mathrm{NH}_{4}\right]^{+}$with a prominent fragment ion peak at $m / z 412$ in agreement with the proposed presence of a sugar moiety $\left(\mathrm{C}_{6} \mathrm{H}_{12} \mathrm{O}_{6}\right)$.

The observation of six methyl signals in the ${ }^{1} \mathrm{H}$ NMR spectrum of 1a at $\delta 0.69(3 \mathrm{H}, d, J=7.0 \mathrm{~Hz})$, $0.70(3 \mathrm{H}, s), 0.71(3 \mathrm{H}, d, J=6.7 \mathrm{~Hz}), 0.76(3 \mathrm{H}, s)$, $0.79(3 \mathrm{H}, d, J=6.8 \mathrm{~Hz}), 0.88(3 \mathrm{H}, d, J=6.6 \mathrm{~Hz})$ indicates that the sterol fragment of $\mathbf{1 a}$ is an ergosterol derivative. The doublet at $\delta 4.2(1 \mathrm{H}, d, J=7.8 \mathrm{~Hz})$ indicates that the attachment of the sugar moiety at $\mathrm{C} 3$ is in the $\beta$-configuration (Shiao et al., 1989; Ahmed, Ahmed \& Malik, 1992; Wasylyk, Martin, Weinheimer \& Alam, 1989), similar to that of the ergosteryl-3- $O$ - $\beta$-D-glucopyranoside (3) and 22,23-dihydroergosteryl-3- $O$ - $\beta$-D-glucopyranoside (4) (Shiao et al., 1989). The observation of the two doublets at $\delta$ $6.39(1 \mathrm{H}, d, J=8.5 \mathrm{~Hz})$ and $6.13(1 \mathrm{H}, d, J=8.5 \mathrm{~Hz})$, approximately $1 \mathrm{ppm}$ downfield of the $\mathrm{H} 6$ and $\mathrm{H} 7$ olefinic protons in $\mathbf{3}$ and $\mathbf{4}$, suggested that the aglycone of $1 \mathrm{a}$ is $5 \alpha, 8 \alpha$-epidioxy-24( $R)$-methylcholesta-6,22-diene$3 \beta$-ol (1b). The close comparison of the ${ }^{13} \mathrm{C}$ data of $\mathbf{1 a}$ with $\mathbf{1 b}$ listed in Table 1 agrees with this proposal.

The identity of the sugar moiety in 1a was not con-<smiles>CC(C)[C@H](C)CC[C@H](C)[C@H]1CCC2C3=CC=C4C[C@@H](O[SiH2])CC[C@]4(C)C3CC[C@]21C</smiles> 
Table 1

${ }^{1} \mathrm{H}$ NMR chemical shifts of isolated compounds from $C$. sinensis

\begin{tabular}{|c|c|c|c|c|c|}
\hline${ }^{1} \mathrm{H}(\mathrm{ppm})$ & $1 \mathrm{a}^{\mathrm{a}}$ & $1 b^{\mathrm{a}}$ & $2^{\mathrm{a}}$ & $3^{\mathrm{b}}$ & $4^{\mathrm{b}}$ \\
\hline $\mathrm{H}-3$ & $3.85(m)$ & $3.92(m)$ & $3.88(m)$ & & \\
\hline H-6 & $6.39(d, J=8.5)$ & $5.95(d, J=8.4)$ & $3.50(d, J=5.1)$ & $5.52(m)$ & $5.27(m)$ \\
\hline $\mathrm{H}-7$ & $6.13(d, J=8.5)$ & $6.29(d, J=8.5)$ & $5.20(d, J=5.2)$ & $5.34(m)$ & $5.35(m)$ \\
\hline Me-18 & $0.70(s)$ & $0.61(s)$ & $0.49(s)$ & $0.58(s)$ & $0.56(s)$ \\
\hline Me-19 & $0.76(s)$ & $0.67(s)$ & $0.95(s)$ & $0.86(s)$ & $0.76(s)$ \\
\hline $\mathrm{Me}-21$ & $0.88(d, J=6.6)$ & $1.00(d, J=6.49)$ & $0.91(d, J=6.6)$ & $1.00(d, J=6.5)$ & $0.91(d, J=6.3)$ \\
\hline $\mathrm{H}-22$ & $5.05(m)$ & $5.25(d d, J=7.6,15.3)$ & $5.09(\mathrm{~m})$ & $5.2(\mathrm{~m})$ & \\
\hline $\mathrm{H}-23$ & $5.09(\mathrm{~m})$ & $5.14(d d, J=8.4,15.3)$ & $5.10(\mathrm{~m})$ & $5.2(\mathrm{~m})$ & \\
\hline Me-26 & $0.69(d, J=7.0)$ & $0.913(d, J=6.8)$ & $0.73(d, J=6.5)$ & $0.80(d, J=6.7)$ & $0.82(d, J=6.9)$ \\
\hline Me-27 & $0.71(d, J=6.7)$ & $0.907(d, J=6.7)$ & $0.71(d, J=6.5)$ & $0.79(d, J=6.7)$ & $0.75(d, J=6.8)$ \\
\hline $\mathrm{Me}-28$ & $0.79(d, J=6.8)$ & $0.99(d, J=6.6)$ & $0.81(d, J=6.8)$ & $0.88(d, J=6.9)$ & $0.85(d, J=7.6)$ \\
\hline $\mathrm{H}-\mathrm{l}^{\prime}$ & $4.23(d, J=7.8)$ & & & $4.24(d, J=7.7)$ & $4.24(d, J=7.7)$ \\
\hline $\mathrm{H}-2^{\prime}$ & 3.10 & & & 2.98 & 2.90 \\
\hline $\mathrm{H}-3^{\prime}$ & 3.13 & & & 3.13 & 3.03 \\
\hline H-4' & 3.25 & & & 3.14 & 3.12 \\
\hline $\mathrm{H}-5^{\prime}$ & 3.30 & & & 3.45 & 3.49 \\
\hline $\mathrm{H}-6 \mathrm{a}^{\prime}$ & 3.50 & & & 3.46 & 3.49 \\
\hline H-6b' & 3.60 & & & 3.61 & 3.59 \\
\hline
\end{tabular}

${ }^{a}{ }^{1} \mathrm{H}$ NMR run in $\mathrm{CDCl}_{3}$.

${ }^{b} \mathrm{H}$ NMR run in d6-DMSO.

clusive from the spectroscopic data. However comparison of the ${ }^{1} \mathrm{H}$ and ${ }^{13} \mathrm{C}$ NMR spectra of 1a with the spectra of the glucopyranosides $\mathbf{3}$ and $\mathbf{4}$ suggests that 1a is also a glucopyranoside. The synthesis of $5 \alpha, 8 \alpha-$ epidioxy-24( $R$ )-methylcholesta-6,22-dien-3 $\beta$-D-glucopyranoside (1a) from ergosterol (6) was carried out as shown in Scheme 1. Deacetylation of 5 (Cerný, Pouzar, Drasar, Budesinsky \& Havel, 1984) followed by a Diels-Alder addition of singlet $\mathrm{O}_{2}\left({ }^{1} \Delta_{\mathrm{g}}\right)$ to the diene in ergosteryl-3- $O-\beta$-D-glucopyranoside (3) (Gunatilaka, Gopichand, Schmitz \& Djerassi, 1981) afforded $\quad 5 \alpha, 8 \alpha$-epidioxy-24( $R$ )-methylcholesta-6,22dien-3 $\beta$-D-glucopyranoside (1a). Comparison of the ${ }^{1} \mathrm{H}$ and ${ }^{13} \mathrm{C}$ NMR of the synthesized molecule both confirmed the proposed identity of the sugar moiety and the stereochemistry of the $5 \alpha, 8 \alpha$-epideoxy functionality in the isolated compound $\mathbf{1 a}$.
$5 \alpha, 8 \alpha$-Epidioxy-24( $R$ )-methylcholesta-6,22-dien-3 $\beta$ D-glucopyranoside has previously been isolated from a variety of fungi (including C. sinensis) (Xiao, Liu \& Tu, 1983; Takaishi, Adachi, Murakami, Ohashi, Nakano \& Tomimatsu, 1992; Tsantrizos, Folkins, Britten, Harpp, Ogilvie, 1992), lichens (Hirayama, Fujikawa, Yosioka \& Kitagawa, 1975; Gonzalez, Barrera, Perez \& Padron, 1992), and marine organisms (Gunatilaka et al., 1981; Guyot \& Durgeat, 1981) and has been shown to have both antitumor (Kahlos, Kangas \& Hiltunen, 1989; Kahlos, Hiltunen \& Kangas, 1989; Matsueda, Shimoyama, Imaizumi \& Tsushima, 1982; Cheng, Nagano, Bang, Ourrison, Beck, 1977) and anti-inflammatory (Yasukawa et al., 1994, 1996) activity. Formation of $\mathbf{1 b}$ was shown to be endogenous in fungi and not an artifact of the isolation procedure (Nes, Xu \& Haddon, 1989).

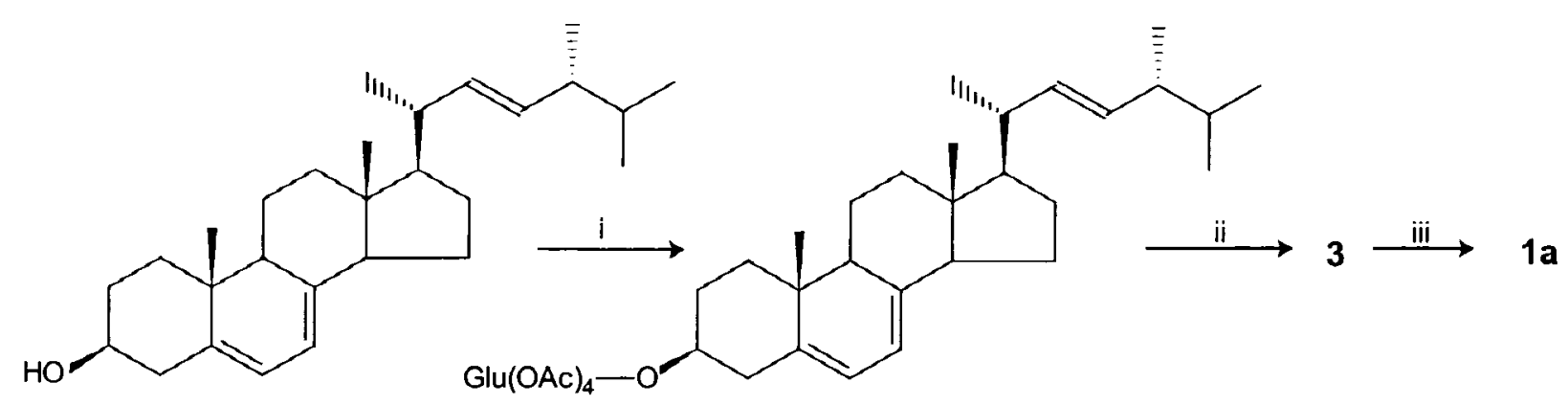

6

Scheme 1. Synthesis of $5 \alpha, 8 \alpha$-epidioxy-24(R)-methylcholesta-6,22-dien-3 $\beta$-D-glucopyranoside (1a); (i) 2,3,4,6-tetra- $O$-acetyl- $\alpha$-D-glucosyltrichloroacetimidate, $\mathrm{CH}_{2} \mathrm{Cl}_{2}, 4 \AA$ mol. sieves, $\mathrm{BF}_{3}$. $\mathrm{Et}_{2} \mathrm{O}$; ii) $\mathrm{MeOH}, \mathrm{Et}_{3} \mathrm{~N}, \mathrm{H}_{2} \mathrm{O}$ (40:6:1) (Gunatilaka, Gopichand, Schmitz \& Djerassi, 1981); (iii) $\mathrm{O}_{2}$, eosin, EtOH, $(500 \mathrm{~W}) h v$. 
The observation of six methyl signals in the ${ }^{1} \mathrm{H}$ NMR spectrum of compound 2, $\delta 0.49(3 \mathrm{H}, s), 0.71$ $(3 \mathrm{H}, d, J=6.5 \mathrm{~Hz}), 0.73(3 \mathrm{H}, d, J=6.5 \mathrm{~Hz}), 0.81(3 \mathrm{H}$, $d, J=6.8 \mathrm{~Hz}), 0.91(3 \mathrm{H}, d, J=6.6 \mathrm{~Hz}), 0.95(3 \mathrm{H}, s)$ indicates that compound $\mathbf{2}$ is also an ergosterol derivative. The molecular formula for compound $\mathbf{2}$ was determined to be $\mathrm{C}_{28} \mathrm{H}_{44} \mathrm{O}_{2}$ by HRMS $\left(\mathrm{M}^{+}=421.3347\right)$. The additional oxygen in the molecular formula of $\mathbf{2}$ in comparison to the molecular formula of ergosterol (6) $\left(\mathrm{C}_{28} \mathrm{H}_{44} \mathrm{O}\right)$ and the observation in the ${ }^{1} \mathrm{H}$ NMR of a signal at $3.50 \mathrm{ppm}$ combined with the loss of an olefinic signal indicates that one of the 5,7-diene olefins in $\mathbf{6}$ has been oxidized to the epoxide. The observation of a correlation in the COSY between the trisubstituted epoxy methine signal at $3.50 \mathrm{ppm}$ and the olefin methine signal at $5.20 \mathrm{ppm}$ is in agreement with this proposal. The observation of cross-peaks in the HMBC between the signal at 5.20 ppm with the ${ }^{13} \mathrm{C}$ signals corresponding to $\mathrm{C} 5, \mathrm{C} 9$ and $\mathrm{C} 14$ and the cross peaks for the signal at $3.50 \mathrm{ppm}$ with the ${ }^{13} \mathrm{C}$ signals corresponding to $\mathrm{C} 5, \mathrm{C} 7, \mathrm{C} 8$ and $\mathrm{C} 10$ indicate the epoxide is in the 5,6 position. The downfield chemical shift of the $3 \beta$-hydroxy methine at $3.90 \mathrm{ppm}$ is consistent with the $\alpha$ stereochemistry for the 5, 6-epoxy group (Aiello, Fattorusso, Magno, Mayol \& Menna, 1990; Isaacs, Berman \& Kashman, 1991; Venkateswarlu, Reddy \& Rao, 1996).

$5 \alpha, 6 \alpha$-Epoxy sterols similar to compound 2 are unknown. A small number of $5 \alpha, 6 \alpha$-epoxy sterols have been isolated from marine sponges and corals (Aiello et al., 1990; Isaacs, Berman \& Kashman, 1991; Venkateswarlu, Reddy \& Rao, 1996; Kobayashi \& Kanda, 1991) and have been shown to have cytotoxic activities.

Growth inhibition due to compounds $\mathbf{1 a}, \mathbf{1 b}$, and $\mathbf{3}$ of the malignant cell lines K562 (erythroleukemia), Jurkat (T-lymphoblastic), HL-60 (promyelocytic leukemia), WM1341 (malignant melanoma) and RPMI 8226 (multiple myeloma) from the American Tissue Type Collection (ATCC) Rockville, MD, were studied to compare their antitumor activity. The percent inhibition of the proliferation of these five malignant cells lines determined from ${ }^{3} \mathrm{H}$-thymidine incorporation assays are shown in Fig. 1(a-d) for 200, 100 and $10 \mu \mathrm{g} / \mathrm{ml}$ concentrations of compounds $\mathbf{3}, \mathbf{1 b}$, and $\mathbf{1 a}$. Compound 3 which does not contain the 5, 8-epoxy functionality showed little to no significant inhibition of proliferation of the tumor cells. Some inhibition of Jurkat and RPMI 8226 was detected at $200 \mu \mathrm{g} / \mathrm{ml}$, the highest concentration in this study. As clearly shown on the graphs, at the lower concentration, the glycoside 1a was found to inhibit proliferation of all five malignant cell lines to a greater extent $(10-40 \%)$ than the aglycone $\mathbf{1 b}$ as a control.

\section{Experimental}

\subsection{General}

IR spectra were acquired with a Bomen FT-IR Michaelson-100 spectrophotometer. The spectra were obtained either in $\mathrm{CHCl}_{3}$ solution using a $0.2 \mathrm{~mm}$ thick $\mathrm{NaCl}$ cell, or as a solid in $\mathrm{KBr}$, and processed using the Bomen Spectra Calc program. LRMS and HRMS were obtained on a Kratos-AEI model MS-50 spectrometer. All spectra were obtained at an ionization energy of $70 \mathrm{eV} .{ }^{1} \mathrm{H}$ NMR spectra were obtained on a Bruker WH-400 spectrometer. ${ }^{13} \mathrm{C}$ and APT were obtained on a Bruker AC-200 spectrometer. HMBC, and HMQC spectra were obtained on a Bruker AMX-500 spectrometer. Silica gel (Art 60, 230-400 mesh) for column chromatography (CC) and silica gel (Kieselgel $60 \mathrm{~F}_{254}$ ) coated on aluminum plates for thin layer chromatography were supplied by Merck.

\subsection{Fungal material}

The mycelial sample of $C$. sinensis was obtained from North American Reishi, Box 1780, Gibsons, British Columbia, Canada, V0N 1 V0.

\subsection{Malignant cell inhibition studies}

${ }^{3} \mathrm{H}$-Thymidine incorporation assays were carried out to determine inhibitory effects. K562 (erythroleukemia), Jurkat (T-lymphoblastic), HL-60 (promyelocytic leukemia), WM1341 (malignant melanoma) and RPMI 8226 (multiple myeloma) malignant cell lines were obtained from the American Tissue Type Collection (ATCC), Rockville, MD. The cell lines were maintained in a medium consisting of RPMI $1640 / \mathrm{FCS} 10 \%$ at $37^{\circ} \mathrm{C}$ in an atmosphere of $5 \%$ $\mathrm{CO}_{2}$. Malignant cell lines, $10^{6}$ cells $/ \mathrm{ml}$ in 96-well round bottom plates (Costar), were cultured with various concentrations of $C$. sinensis extracts in a $5 \% \mathrm{CO}_{2}$-air humidified atmosphere at $37^{\circ} \mathrm{C}$. After $16 \mathrm{~h}$ of coculture, ${ }^{3} \mathrm{H}$-thymidine ( $1 \mathrm{MCi} /$ well, Dupont, Montreal) was added to each well. ${ }^{3} \mathrm{H}$-Thymidine uptake was measured after 6 hours of incubation using a scintillation counter. The inhibitory effect of each extract on tumor cell proliferation was calculated using Eq. 1.

Inhibition percent $(\%)$

$$
\begin{aligned}
= & \frac{\text { Control group }(\mathrm{cpm})-\text { Experimental group }(\mathrm{cpm})}{\text { Control group }(\mathrm{cpm})} \\
& \times 100
\end{aligned}
$$



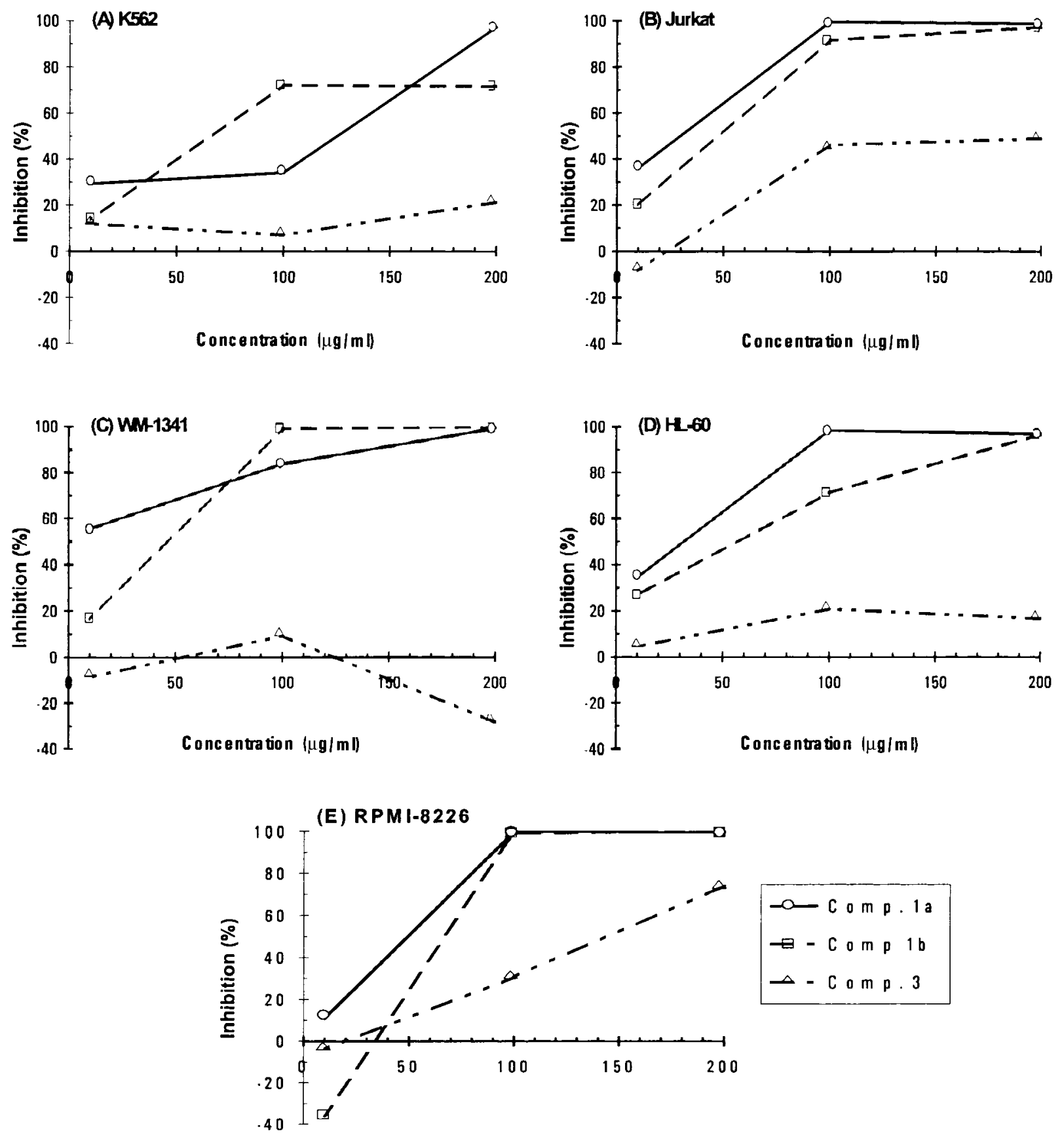

Concentration $(\mu \mathrm{g} / \mathrm{m})$

Fig. 1. Growth inhibition activities of $5 \alpha, 8 \alpha$-epidioxy-24( $R$ )-methylcholesta-6,22-dien-3 $\beta$-D-glucopyranoside (1a), $5 \alpha, 8 \alpha$-epidioxy-24( $R$ )-methylcholesta-6,22-diene-3 $\beta$-ol (1b) and ergosteryl-3-O- $\beta$-D-glucopyranoside (3) on (A) K562 cell line, (B) Jurkat cell line (C) WM-1341cell line, (D) HL60 cell line, (E) RPMI-8226 cell lines. Each point represents means of three independent experiments $(\mathrm{SD} \leq 7 \%)$.

\subsection{Activity guided fractionation of fungal material}

The dry mycelium of $C$. sinensis $(150 \mathrm{~g})$ was extracted with $\mathrm{MeOH}$ three times $(500 \mathrm{ml} \times 3)$. The $\mathrm{MeOH}$ extracts were combined and the solvent was removed under reduced pressure. The crude $\mathrm{MeOH}$ extract was found to inhibit K562 proliferation by
$36 \%$ at $500 \mu \mathrm{g} / \mathrm{ml}$, in the ${ }^{3} \mathrm{H}$-thymidine incorporation assay. The residue was then redissolved in $\mathrm{MeOH} / \mathrm{H}_{2} \mathrm{O}$ (1:1) and washed with hexanes. Methanol was distilled from the aqueous layer under reduced pressure. The remaining aqueous layer was extracted with EtOAc. Concentration of the combined EtOAc extracts under reduced pressure provided $1.57 \mathrm{~g}$ of a brown oil (B1). 
This residue was chromatographed on a silica gel-flash column $(230-400$ mesh, $50 \times 8.0 \mathrm{~cm})$. The elution was started with $\mathrm{CHCl}_{3}$ and the polarity of solvents was increased stepwise in the following sequence: $\mathrm{CHCl}_{3}$, $\mathrm{CHCl}_{3} / \mathrm{MeOH}$ (8:2), $\mathrm{CHCl}_{3} / \mathrm{MeOH}$ (5:5), $\mathrm{CHCl}_{3} /$ $\mathrm{MeOH}(2: 8)$ and $\mathrm{MeOH}$. Fourteen fractions (FA1FA14) were collected and dried in vacuo. Only one fraction (FA8) was found have antitumor activity. Fraction FA8 was further chromatographed on a silicagel flash-column eluted with $\mathrm{CHCl}_{3} / \mathrm{MeOH}(8: 2)$ to afford two fractions $\mathrm{FB} 1$ and $\mathrm{FB} 2$ having an $R f=6.3$ and 5.4, respectively. FB1 was a white solid $(38 \mathrm{mg})$. Recrystallization of $\mathrm{FB} 1$ in $\mathrm{CHCl}_{3}$ afforded $10 \mathrm{mg}$ of 2 as a white powder. Compound $\mathbf{2}$ was found to have $61 \%$ antitumor activity against Jurkat cells and 36.3\% activity against K562 cells at $100 \mu \mathrm{g} / \mathrm{ml}$. Fraction FB2 was found to have $96 \%$ activity against Jurkat cells and $77 \%$ activity against K562 cancer cells at $100 \mu \mathrm{g} /$ ml. FB2 was further separated by silica gel chromatography eluted with $\mathrm{Et}_{2} \mathrm{O}$ :hexanes: $\mathrm{MeOH}=5: 5: 1$ to afford two fractions $\mathrm{FCl}(R f=6.3)$ and $3 \mathrm{mg}$ of compound 1a $(R f=5.4)$ as a white solid. FC1 was further separated by HPLC to give 3 and $\mathbf{4}$.

3.4.1. $5 \alpha, 6 \boldsymbol{\alpha}$-Epoxy-24(R)-methylcholesta-7,22-dien-3及ol (2).

IR $\left(\mathrm{cm}^{-1}, \mathrm{CHCl}_{3}\right): 4685-3110$ (hydroxyl), 2950, 2880, 1673, 1462; ${ }^{1} \mathrm{H}$ NMR $\left(500 \mathrm{MHz}, \mathrm{CDCl}_{3}\right) \delta: 0.49$ $(3 \mathrm{H}, s, \mathrm{Me}-18), 0.72(3 \mathrm{H}, d, J=6.5$, Me-26 or 27$), 0.73$ $(3 \mathrm{H}, d, J=6.5, \mathrm{Me}-26$ or 27$), 1.2(2 \mathrm{H}, m, \mathrm{H} 17, \mathrm{H} 16)$, $1.32(1 \mathrm{H}, m, \mathrm{H} 2), 1.36(1 \mathrm{H}, m, \mathrm{H} 25), 1.44-1.48(4 \mathrm{H}$, $\left.m, \mathrm{H} 11, \mathrm{H} 11^{\prime}, \mathrm{H} 15, \mathrm{H} 1\right), 1.58(1 \mathrm{H}, m, \mathrm{H} 12), 1.64(1 \mathrm{H}$, $\left.m, \mathrm{H} 16^{\prime}\right), 1.72\left(1 \mathrm{H}, m, \mathrm{H} 2{ }^{\prime}\right), 1.75(1 \mathrm{H}, m, \mathrm{H} 24), 1.81$ (1H, m, H14), $1.85(1 \mathrm{H}, m, \mathrm{H} 9), 1.94(1 \mathrm{H}, m, \mathrm{H} 20)$, $1.95(1 \mathrm{H}, m, \mathrm{H} 4), 3.5(1 \mathrm{H}, d, J=5.1, \mathrm{H}-6), 3.9(1 \mathrm{H}, m$, $\mathrm{H}-3), 5.09(1 \mathrm{H}, m, \mathrm{H}-22), 5.11(1 \mathrm{H}, m, \mathrm{H}-23), 5.2(1 \mathrm{H}$, $m, \mathrm{H}-7) ;{ }^{13} \mathrm{C}$ NMR $\left(50 \mathrm{MHz}, \mathrm{CDCl}_{3}\right)$ listed in Table 2; LRMS (EI) $m / z$ (rel. int. \%): $413[\mathrm{M}+1]^{+}$, $396[\mathrm{M}-16]^{+}$; HRMS (EI): Calculated for $\mathrm{C}_{28} \mathrm{H}_{44} \mathrm{O}_{2}$ : 412.33414; found: 412.33477 .

\subsection{2. $5 \boldsymbol{\alpha}, 8 \boldsymbol{\alpha}$-epidioxy-24( $R$ )-methylcholesta-6,22-dien- 3及-D-glucopyranoside (1a)}

IR $\left(\mathrm{cm}^{-1}, \mathrm{CHCl}_{3}\right)$ : 3580-3055 (hydroxyl), 2950, $2873,1681,1458,1371 ;[\alpha]_{\mathrm{D}}\left(25^{\circ} \mathrm{C}\right):-15.6^{\circ} ;{ }^{1} \mathrm{H}$ NMR $\left(500 \mathrm{MHz}, \mathrm{CDCl}_{3}\right) \delta: 0.70(3 \mathrm{H}, d, J=6.7, \mathrm{Me}-26$ or Me-27), $0.71(3 \mathrm{H}, s, \mathrm{Me}-18), 0.72(3 \mathrm{H}, d, J=6.7$, Me26 or Me-27), $0.79(3 \mathrm{H}, d, J=6.8 \mathrm{~Hz}, \mathrm{Me}-28), 0.76$ $(3 \mathrm{H}, s, \mathrm{Me}-19), 0.88(3 \mathrm{H}, d, J=6.6 \mathrm{~Hz}, \mathrm{Me}-21), 1.0-$ $2.0(19 \mathrm{H}, m), 2.1(1 \mathrm{H}, m), 3.1-3.2\left(2 \mathrm{H}, m, \mathrm{H}-2^{\prime}, \mathrm{H}-\right.$ 3'), 3.2-3.4 (2H, m, H-4', H-5'), 3.5 (1H, $\left.m, \mathrm{H}-6 \mathrm{a}^{\prime}\right)$, $3.60\left(1 \mathrm{H}, m, \mathrm{H}_{6} \mathrm{~b}^{\prime}\right), 3.85(1 \mathrm{H}, m, \mathrm{H}-3) ; 4.23(1 \mathrm{H}, d$, $\left.J=7.8 \mathrm{~Hz}, \mathrm{H}-1^{\prime}\right), 5.05(1 \mathrm{H}, m, \mathrm{H}-22), 5.09(1 \mathrm{H}, m, \mathrm{H}-$ 23), $6.13(1 \mathrm{H}, d, J=8.5 \mathrm{~Hz}, \mathrm{H}-7), 6.39(1 \mathrm{H}, d$, $J=8.5 \mathrm{~Hz}, \mathrm{H}-6) ;{ }^{13} \mathrm{C}$ NMR $\left(50 \mathrm{MHz}, \mathrm{CDCl}_{3}\right)$ : Table 2; LRMS (CIMS) $m / z$ (rel. int.): $608\left[\mathrm{M}+\mathrm{NH}_{4}\right]^{+}$,
Table 2

${ }^{13} \mathrm{C}$ NMR chemical shifts of the isolated compounds from $C$. sinensis $5 \alpha, 8 \alpha$-epidioxy-24( $R$ )-methylcholesta-6,22-dien-3 $\beta$-D-glucopyranoside (1a), $5 \alpha, 6 \alpha$-epoxy-24( $R$ )-methylcholesta-7,22-dien-3 $\beta$-ol (2), ergosteryl-3- $O$ - $\beta$-D-glucopyranoside (3) and for comparison compound $5 \alpha, 8 \alpha$-epidioxy-24( $R$ )-methylcholesta-6,22-diene-3 $\beta$-ol (1b)

\begin{tabular}{|c|c|c|c|c|}
\hline Carbon & $1 \mathrm{a}$ & $1 \mathrm{~b}$ & 2 & 3 \\
\hline 1 & 33.6 & 39.4 & 32.6 & 36.9 \\
\hline 2 & 29.7 & 30.1 & 30.6 & 29.5 \\
\hline 3 & 74.5 & 66.3 & 67.2 & 73.3 \\
\hline 4 & 51.2 & 51.2 & 38.7 & 37.9 \\
\hline 5 & 79.4 & 79.4 & 75.7 & 139.0 \\
\hline 6 & 130.6 & 130.7 & 72.7 & 119.6 \\
\hline 7 & 135.5 & 135.4 & 117.3 & 115.9 \\
\hline 8 & 82.1 & 82.7 & 143.8 & 141.1 \\
\hline 9 & 34.8 & 34.7 & 43.0 & 45.9 \\
\hline 10 & 37.0 & 36.9 & 36.8 & 29.3 \\
\hline 11 & 20.8 & 20.9 & 21.8 & 20.7 \\
\hline 12 & 39.4 & 39.4 & 39.1 & 38.7 \\
\hline 13 & 44.6 & 44.6 & 43.3 & 42.5 \\
\hline 14 & 51.7 & 51.7 & 54.3 & 54.2 \\
\hline 15 & 28.7 & 28.6 & 22.7 & 22.6 \\
\hline 16 & 23.4 & 23.4 & 27.8 & 27.6 \\
\hline 17 & 56.3 & 56.3 & 55.8 & 55.4 \\
\hline 18 & 12.9 & 12.9 & 12.1 & 11.6 \\
\hline 19 & 18.2 & 18.7 & 18.0 & 15.7 \\
\hline 20 & 39.8 & 39.7 & 40.2 & 40.1 \\
\hline 21 & 19.7 & 19.6 & 20.9 & 20.6 \\
\hline 22 & 132.3 & 132.3 & 135.7 & 135.3 \\
\hline 23 & 135.3 & 135.2 & 131.9 & 131.6 \\
\hline 24 & 42.8 & 42.8 & 42.6 & 42.5 \\
\hline 25 & 33.1 & 33.0 & 32.9 & 32.7 \\
\hline 26 & 19.9 & 19.9 & 19.7 & 22.6 \\
\hline 27 & 20.9 & 20.7 & 19.4 & 19.4 \\
\hline 28 & 17.8 & 17.5 & 17.4 & 17.1 \\
\hline $1^{\prime}$ & 101.2 & & & 100.9 \\
\hline $2^{\prime}$ & 73.3 & & & 73.3 \\
\hline $3^{\prime}$ & 75.5 & & & 76.2 \\
\hline $4^{\prime}$ & 69.6 & & & 69.8 \\
\hline $5^{\prime}$ & 78.1 & & & 77.4 \\
\hline $6^{\prime}$ & 61.5 & & & 61.5 \\
\hline
\end{tabular}

$593[\mathrm{M}+2]^{+}, \quad 590[\mathrm{M}]^{+}, \quad 412[\mathrm{M}-178]^{+} ; \quad$ HRMS (DCIMS): Calculated for $\mathrm{C}_{34} \mathrm{H}_{54} \mathrm{O}_{8}+\mathrm{NH}_{4}^{+}$: 608.41624; found: 608.41572 .

\subsection{Synthesis of $\mathbf{1 a}$ from ergosterol (6)}

All reactions were carried out under nitrogen atmosphere in flame-dried glassware unless otherwise stated.

\subsubsection{2,3,4,6-Tetra-O-acetyl-3-O- $\boldsymbol{\beta}$-D-glucopyranosyl- ergosta-6,22-dien-5 $\boldsymbol{\alpha}, 8 \boldsymbol{\alpha}$-epidioxy-3 $\boldsymbol{\beta}$-ol ( 5 )}

To a stirring solution of 2,3,4,6-tetra- $O$-acetyl- $\alpha$-Dglucosyl trichloroacetimidate $(0.172 \mathrm{~g}, 0.4 \mathrm{mmol})$ in $10 \mathrm{ml}$ dry $\mathrm{CH}_{2} \mathrm{Cl}_{2}$ was added $4 \AA$ molecular sieves $(1 \mathrm{~g})$ followed by ergosterol (6) $(0.2 \mathrm{~g}, 0.5 \mathrm{mmol})$ as a solid powder. The solution was cooled to $0^{\circ} \mathrm{C}$ prior to the dropwise addition of $\mathrm{BF}_{3} \cdot \mathrm{Et}_{2} \mathrm{O}(0.4 \mathrm{ml}$ of stock $30 \mu \mathrm{l}$ in $2.5 \mathrm{ml} \mathrm{CH}_{2} \mathrm{Cl}_{2}$ ). Upon the addition of $\mathrm{BF}_{3} \cdot \mathrm{Et}_{2} \mathrm{O}$ the 
solution turned pink, then quickly returned to a clear colourless solution. After $10 \mathrm{~min}$ the solution was allowed to warm slowly to room temperature. The reaction was quenched with the addition of $\mathrm{Et}_{3} \mathrm{~N}$ $(60 \mu \mathrm{l})$ after $40 \mathrm{~min}$. The clear solution was diluted with $\mathrm{CH}_{2} \mathrm{Cl}_{2}$, filtered to remove the molecular sieves and washed twice with $\mathrm{H}_{2} \mathrm{O}$. The organic layer was concentrated under reduced pressure. Column chromatography eluted with $5 \% \mathrm{MeOH}$ in $\mathrm{CHCl}_{3}$ afforded $\mathbf{5}$ $(0.0466, \mathrm{mmol})$ in $16 \%$ yield $(R f=0.78,15 \% \mathrm{MeOH}$ in $\mathrm{CHCl}_{3}$ ) followed by unreacted starting material $(0.1192 \mathrm{~g}, 300 \mathrm{mmol})(R f=0.66,15 \% \mathrm{MeOH}$ in $\left.\mathrm{CHCl}_{3}\right) .{ }^{1} \mathrm{H}$ NMR $\left(400 \mathrm{MHz}, \mathrm{CDCl}_{3}\right) \delta: 0.59(3 \mathrm{H}, s$, Me-18), $0.79(3 \mathrm{H}, d, J=6.7$, Me-26 or 27$), 0.80(3 \mathrm{H}, d$, $J=6.7$, Me-26 or 27), $0.86(3 \mathrm{H}, d, J=6.9$, Me-28), $0.88(3 \mathrm{H}, s, \mathrm{Me}-19), 1.00(3 \mathrm{H}, d, J=6.5$, Me-21), $1.7-$ $2.0(18 \mathrm{H}, m) 1.98(3 \mathrm{H}, s), 1.99(3 \mathrm{H}, s), 2.01(3 \mathrm{H}, s)$, $2.03(3 \mathrm{H}, s), 2.21(1 \mathrm{H}, m), 2.40(1 \mathrm{H}, m), 3.56(1 \mathrm{H}, m$, $\mathrm{H}-3), 3.66(1 \mathrm{H}, m), 4.10(1 \mathrm{H}, m), 4.24(1 \mathrm{H}, m), 4.60$ $\left(1 \mathrm{H}, d, J=7.7, \mathrm{H}^{\prime} 1^{\prime}\right), 4.94(1 \mathrm{H}, m), 5.04(1 \mathrm{H}, m), 5.18$ $(3 \mathrm{H}, m, \mathrm{H}-22, \mathrm{H}-23), 5.36(1 \mathrm{H}, m, \mathrm{H}-7), 5.55(1 \mathrm{H}, m$, $\mathrm{H}-6) ;{ }^{13} \mathrm{C}$ NMR $\left(50 \mathrm{MHz}, \mathrm{CDCl}_{3}\right) 12.0,16.1,17.6$, 19.2, 19.6, 19.6, 19.9, 20.5, 20.6, 20.7, 21.0, 22.9, 28.2, $29.7,33.0,33.0,37.1,37.4,38.2,39.0,40.3,42.8,46.1$, $54.5,55.7,62.0,68.5,71.4,71.7,72.8,78.6,99.5,116.1$, $119.9,131.9,135.4,139.0,141.6,169.2,169.3,170.3$, 170.6 .

\subsubsection{Ergosteryl-3-O-B-D-glucopyranoside (3)}

To a stirring solution of $5(0.0564 \mathrm{~g}, 0.078 \mathrm{mmol})$ in $20 \mathrm{ml} \mathrm{MeOH}$ was added $3 \mathrm{ml} \mathrm{Et}_{3} \mathrm{~N}$ and $0.5 \mathrm{ml} \mathrm{H}_{2} \mathrm{O}$. After stirring for $48 \mathrm{~h}$ the solvent was removed under reduced pressure. The residue was applied to a silica gel column, and eluted with $15 \% \mathrm{MeOH}$ in $\mathrm{CHCl}_{3}$ $(R f=20.6)$ to afford a white solid. Recrystallization from $\mathrm{MeOH}$ provided $3(0.0351 \mathrm{~g}, 0.063 \mathrm{mmol})$ in $81 \%$ yield as small white needles. IR $\left(\mathrm{cm}^{-1}, \mathrm{CHCl}_{3}\right)$ : $3400, \quad 2950, \quad 2875, \quad 1681,1458,1371 ;{ }^{1} \mathrm{H}$ NMR (400 MHz, DMSO) $\delta: 0.58(3 \mathrm{H}, s, \mathrm{Me}-18), 0.79(3 \mathrm{H}$, $d, J=6.7, \mathrm{Me}-26$ or -27$), 0.80(3 \mathrm{H}, d, J=6.7, \mathrm{Me}-26$ or -27), 0.86 ( $3 \mathrm{H}, s, \mathrm{Me}-19), 0.88$ (3H, $d, J=6.9, \mathrm{Me}-28)$, $1.00(3 \mathrm{H}, d, J=6.5, \mathrm{Me}-21), 1.24(2 \mathrm{H}, m) 1.45(1 \mathrm{H}$, $m), 1.6(1 \mathrm{H}, m) 1.68(1 \mathrm{H}, m), 1.85(2 \mathrm{H}, m), 2.0(1 \mathrm{H}$, $m), 2.18(1 \mathrm{H}, m), 2.54(1 \mathrm{H}, m), 2.98(1 \mathrm{H}, m), 3.13$ $(1 \mathrm{H}, m), 3.14(1 \mathrm{H}, m), 3.3(1 \mathrm{H}, \mathrm{bs}), 3.46(2 \mathrm{H}, m)$, $3.61(1 \mathrm{H}, m), 4.24\left(1 \mathrm{H}, d, J=7.7 \mathrm{~Hz}, \mathrm{H}-1^{\prime}\right), 5.20(2 \mathrm{H}$, $m, \mathrm{H}-22, \mathrm{H}-23), 5.34(1 \mathrm{H}, m, \mathrm{H}-7), 5.52(1 \mathrm{H}, m, \mathrm{H}-6)$; ${ }^{13} \mathrm{C}$ NMR $\left(50 \mathrm{MHz}, \mathrm{CDCl}_{3}\right.$,): Table 2.

\subsection{3. $5 \alpha, 8 \boldsymbol{\alpha}$-Epidioxy-24( $R$ )-methylcholesta-6,22-dien- $3 \boldsymbol{\beta}$-D-glucopyranoside (1a)}

To a solution of $3(0.0211 \mathrm{~g}, 0.038 \mathrm{mmol})$ in $20 \mathrm{ml}$ dry EtOH was added 2 drops of a $10 \%$ solution of eosin in EtOH. Oxygen was bubbled through the solution. The reaction vessel was then placed in a silver dewa and irradiated with a $500 \mathrm{~W}$ tungsten lamp.
Water was circulated into the dewar to maintain room temperature for the reaction. After $3 \mathrm{~h}$ the solution was concentrated under reduced pressure, with the resulting residue applied to a silica gel column what we eluted with $15 \% \mathrm{MeOH}$ in $\mathrm{CHCl}_{3}$ to afford 1a $(0.0138 \mathrm{~g}, 0.023 \mathrm{mmol})$ in $62 \%$ yield as a white solid. IR, ${ }^{1} \mathrm{H},{ }^{13} \mathrm{C}$ and LRMS were identical to spectra of $\mathbf{1 a}$ isolated from the mycelia of $C$. sinensis.

\subsubsection{Synthesis of $5 \boldsymbol{\alpha}, 8 \boldsymbol{\alpha}$-epidioxy-24( $R$ )-methyl-

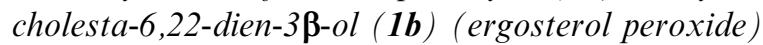 from ergosterol (6)}

Following the same procedure as used for the preparation of 1a from 3, ergosterol (6) (0.1040 g , $0.26 \mathrm{mmol}$ ) was oxidized, then purified by silica gel column eluted with $15 \%$ EtOAc in $\mathrm{CH}_{2} \mathrm{Cl}_{2}$ to afford $1 \mathrm{~b}(0.0932 \mathrm{~g}, 0.22 \mathrm{mmol})$ in $85 \%$ yield as a white solid. ${ }^{1} \mathrm{H}$ NMR $\left(500 \mathrm{MHz}, \mathrm{CDCl}_{3}\right) \quad 0.61(3 \mathrm{H}, s, \mathrm{Me}-$ 18), $0.67(3 \mathrm{H}, s, \mathrm{Me}-19), 0.907(3 \mathrm{H}, d, J=6.67 \mathrm{~Hz}$, Me-26 or 27$), 0.913(3 \mathrm{H}, d, J=6.71 \mathrm{~Hz}, \mathrm{Me}-26$ or -27$)$, $0.99(3 \mathrm{H}, d, J=6.78 \mathrm{~Hz}, \mathrm{Me}-28), 1.00(3 \mathrm{H}, d, J=6.49$, Me-21), 1.1-2.0 (20H, m), $3.92(\mathrm{~m}, 1 \mathrm{H}, \mathrm{H}-3), 5.14$ $(1 \mathrm{H}, m, \mathrm{H}-23), 5.25(1 \mathrm{H}, m, \mathrm{H}-22), 5.95(1 \mathrm{H}, d$, $J=8.37 \mathrm{~Hz}, \mathrm{H}-6), 6.29(1 \mathrm{H}, d, J=8.47 \mathrm{~Hz}, \mathrm{H}-7) ;{ }^{13} \mathrm{C}$ NMR (50 MHz, $\mathrm{CDCl}_{3}$ ): Table 2.

\section{Acknowledgements}

This work was supported by North American Reishi Inc., British Columbia. We also thank Dr S. G. Withers for providing 2,3,4,6-tetra- $O$-acetyl- $\alpha$-D-glucosyltrichloroacetimidate.

\section{References}

Ahmed, W., Ahmed, Z., \& Malik, A. (1992). Phytochemistry, 31, 4038.

Aiello, A., Fattorusso, E., Magno, S., Mayol, L., \& Menna, M. (1990). J. Nat. Prod., 53, 487.

Cerný, I., Pouzar, V., Drasar, P., Budesinsky, M., \& Havel, M. (1984). Collct. Czech. Chem. Commun., 49, 881.

Cheng, K. P., Nagano, H., Bang, L., Ourrison, G., \& Beck, J. P. (1977). Chem. Res., Sup., 9, 217.

Cunningham K.G., Herchinson S.A., Manson W., Spring F.S. 1951 J. Chem. Soc. 2299.

Furuya, T., Hirotani, M., \& Matsuzawa, M. (1983). Phytochemistry, 22, 2509

Gonzalez, A. G., Barrera, J. D., Perez, E. M. R., \& Padron, C. E. H. (1992). Planta Med., 58, 214.

Gunatilaka, A. A. L., Gopichand, Y., Schmitz, F. J., \& Djerassi, C. (1981). J. Org. Chem., 46, 3860.

Guyot, M., \& Durgeat, M. (1981). Tetrahedron Lett., 22, 1391.

Hirayama, T., Fujikawa, F., Yosioka, I., \& Kitagawa, I. (1975). Chem. Pharm. Bull. Jpn, 23, 693.

Isaacs, S., Berman, R., \& Kashman, Y. (1991). J. Nat. Prod., 54, 83.

Jones, K. (1993). A brief pharmacologic review of Cordyceps sinensis and C. ophiolglossoides. Armana Research. 
Kahlos, K., Hiltunen, R., \& Kangas, L. (1989). Fitoterapia, 60, 166.

Kahlos, K., Kangas, L., \& Hiltunen, R. (1989). Planta Med., 55, 389.

Kneifel, H., Srinivasan, K. S., \& Maiti, P. C. (1957). J. Am. Pharm., $113,121$.

Kobayashi M., Kanda F. (1991) J. Chem. Soc., Perkin Trans. I, 1177.

Kredich, N. M., \& Guarino, A. J. (1960). Biochim. Biophys. Acta, 41, 363.

Kuo, Y-C., Ching-Yuang, Lin C-Y., Wei-Jern, Tsai W-J., Wu, C-L., Chen, C-F., \& Shiao, M-S. (1994). Cancer Invest., 12, 611.

Matsueda, S., Shimoyama, M., Imaizumi, T., \& Tsushima, Y. (1982). Yakugaku Zasshi, 102, 347.

Miyazaki, T., Oikawa, N., \& Yamada, H. (1977). Chem. Pharm. Bull., 25, 3324.

Nes, D. W., Xu, S., \& Haddon, W. F. (1989). Steroids, 53, 533.

Ohmori, T., Tamura, K., Tsuru, S., \& Nomoto, K. (1986). Jpn J. Cancer Res., 77, 1256.

Pegler, D. N., Yao, Y-J., \& Li, Y. (1994). Mycologist, 8, 1.

Shiao, M-S., Lin, L-J., Lien, C-Y., Tzean, S-S., \& Lee, K. R. (1989), Proc. Natl. Sci. Counc. ROC(A), 13, 382.

Steinkraus, D. C., \& Whitfield, J. B. (1994). American Entomologist, $40,235$.
Takaishi, Y., Adachi, R., Murakami, Y., Ohashi, T., Nakano, K., \& Tomimatsu, T. (1992). Phytochemistry, 31, 243.

Tsantrizos, Y. S., Folkins, P. L., Britten, J. F., Harpp, D. N., \& Ogilvie, K. K. (1992). Can. J. Chem., 70, 158.

Tsunoo, A., Taketomo, N., Tsuboi, H., Kamijio, M., Nemoto, A., Sasaki, H., Uchida, M., Yamashita, A., Kinjo, N., \& Haung, NL. (1995). In: A. Tsunoo, N. Taketomo, H. Tsuboi, M. Kamijio, A. Nemoto, H. Sasaki, M. Uchida, A. Yamashita, N. Kinjo, \& N-L. Haung. Cordyceps sinensis; Its diverse effects on mammals in vitro and in vivo. Chiba, Japan.

Venkateswarlu, Y., Reddy, M. V. R., \& Rao, M. R. (1996). J. Nat. Prod., 59, 876.

Wasylyk, J. M., Martin, G. E., Weinheimer, A. J., \& Alam, M. (1989). J. Nat. Prod., 52, 391.

Xiao, Y., Liu, J., \& Tu, Y. (1983). Zhongyao Tongbao, 8, 32.

Yamada, H., Kawagichi, N., Ohmori, T., Takeshita, Y., Taneya, S., \& Yamazaki, T. (1984). Carbohydr. Res., 125, 107.

Yasukawa, K., Aoki, T., Takida, M., Ikekawa, T., Shaito, H., \& Matsuzawa, T. (1994). Phytotheraphy Res., 8, 10.

Yasukawa, K., Akihisa, T., Kanno, H., Tomohiro, I., Izumida, M., Sakoh, T., Tamura, T., \& Takido, M. (1996). Biol. Pharm. Bull., 19, 573.

Zhang, S., Zhang, D., Zhu, T., \& Chen, X. (1991). Acta Pharm. Sin., $26,326$. 